\title{
State's Medical Experts in Local Practice Provincial Doctors View of Themselves as Public Health Promoters: an Example from the Swedish Countryside, $1880-1920$
}

\author{
Anna Prestjan
}

\section{Introduction}

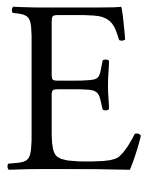
ven if the Swedish welfare state made its breakthrough and really was expanded in the 1930's and 1940's, the first steps were taken at the end of the $19^{\text {th }}$ century. These early welfare strivings were mainly expressed through public health care measures, and public health care has since then been a prioritised part of the welfare state. ${ }^{1}$ From now on, a national system for public health and medical services was established, and the role of medicine in social planning increased. ${ }^{2}$ Medical science developed, medical care conformed to governmental administration and medical services expanded quantitatively concerning medical professions, specialisation, institutions and beds. ${ }^{3}$ From a perspective of professionalisation, this meant that trained experts, the professional medical agents, came to play an increasing part in the Swedish state's efforts to solve different social problems, and that profession became more important than class. ${ }^{4}$

Many scholars have pointed out that Sweden, in an international perspective, distinguishes itself in the early organizing of a public health care project with medical legislation, public medical authorities on a central as well as on local level, and a

1 Esping-Andersen in Thullberg \& Östberg (eds) 1994, pp. 79-85, Sundin in Carlsson \& Arvidsson (eds) 1994, p. 77, Lundqvist 2001, p. 754, Erikson 2003, p. 221, Sundin in Sundin, Hogstedt, Lindberg \& Moberg (eds) 2005, p. 365, Bernsen in Ervik \& Kuhnle (eds) 1993, pp. 72, 80-83, 99-100.

2 Seip 1984, pp. 12-13, Åmark 2005, p. 26, Berge 2007, p. 13, Sundin 2005, p.397, Qvarsell 1991, pp. 166-167, 173-174.

3 Palmblad 1990, passim, esp. pp. 9-12, Clark Nelson in Att se det osedda : vänbok till Ann-Sofie Oblander 2006, pp. 98-113, Qvarsell \& Torell in Qvarsell \& Torell 2000, p.9.

4 Perkin 1989, Eklöf 2000. 
system in which the majority of all medical professionals were state employed. ${ }^{5}$ These measures were foremost justified on the basis of contemporary ideas of the unhealthy and dangerous city, in some parts based on real needs demanded by the industrialization and urbanisation of the growing cities. Research, then, also focuses how public health reforms were put in to practice in Swedish cities, not in the countryside. ${ }^{6}$ City or countryside, it has been noticed that we have comparatively little knowledge of the citizens' encounter with the welfare state, that is, of the citizens needs for, use of and benefit of the welfare services. ${ }^{7}$ Even though the importance of the local perspective has been pointed out, ${ }^{8}$ as well as the importance of the local, individual agents to the development of public health, " research on how public health care was practiced and on what effects public health care policy had on a local level is scarce.

By studying the provincial doctors as the state's medical experts in local practice, one can produce knowledge on a) how (in the meaning when, to what extent and in what ways) public health as policy and practice was implemented in the Swedish countryside communities, and b) on the part played by the experts as agents in the development of the Swedish welfare state. This article is based upon a case study of a small and sparsely populated medical district in the middle of Sweden, the Sveg district, during the period 1880-1920.

\section{The Local - Central Perspective}

One way to approach the problem - how public health care policy was realised in local communities - is to analyze these communities as medical marketplaces, ${ }^{11}$ where different kinds of health and medical services are offered and used in a geographically limited area. It has, though, been claimed that physicians in Sweden, where the private practitioners have been comparatively few in an early state regulated medical sphere, don't have had any reason to guard their own interests in

5 Ling 2004, pp. 23, 25, Sundin, Hogstedt, Lindberg \& Moberg 2005, p. 24-26, Kearns in Clark Nelson \& Rogers (eds) 1989, pp. 7-81, esp. p. 24,

6 Sundin 2005, pp. 400-403, Sköld 1996, p. 94-95, Edvinsson 1992, Nilsson 1994, Edvinsson \& Rogers 2001, pp. 541-564.

7 Erikson 2003, pp. 221-222.

8 Qvarsell 1994, p. 105, Sköld 1996, pp. 94-95, Larsson 2004, p. 40.

9 Sundin, Hogstedt, Lindberg \& Moberg in Sundin, Hogstedt, Lindberg \& Moberg (eds.) 2005, pp. 19-34, Edvinsson \& Rogers 2001, pp. 543.

10 Sundin in Carlsson \& Arvidsson (eds.), p. 70.

11 According to the British historians Mark Jenner and Patrick Wallis, this perspective is rewarding, presupposed that the concept of medical market(place) is properly defined in every specific case, Jenner \& Wallis 2007 (eds.), p. 3. 
competition with others on a market. ${ }^{12}$ Anyway, even if more or less state regulated, the Swedish medical market never have been fully monopolized by the public health system and its agents. For example, Swedish historians Motzi Eklöf and Sofia Ling have used the medical market terminology to point out that medical pluralism, in spite of early state regulation, has been a fact in Sweden even until today. ${ }^{13}$ As long as there is a choice, supply and demand, there is a market. I suggest, then, that the terminology and concept of medical marketplace can be used to analyse what happens when ideas of public health confront reality in local societies, and that the welfare state's public health policies can be expressed as a striving towards domination and control of all Swedish medical marketplaces, meaning that all citizens should get access to, but also chose and use, the public health and medical care instead of other options.

The term medical marketplace also stresses the study's focus on local societies. The relation and interaction between the local level and the central plays an important part in this study. This relation shall be understood as both analytical and geographical. Analytically, the relation is between structures and practices. Professional and political interests are expressed through medical legislations, recommendations and instructions. This composes a framework - a structure intending to regulate the practices of the medical agents - here, the provincial doctors as represents of a public and centrally organized health care system. The provincial doctors were expected to perform their duties in accordance to this framework: to pass on medical science and health care policies to the local community and turn it into practice. On the other hand, obviously the provincial doctors had to adjust their practice to the specific conditions of the physical place. ${ }^{14}$

The local-central-relation is also a geographic relation between the Swedish cities as political, academic and cultural centres and "the rest of Sweden", in a period when the absolute majority of the Swedish population still lived in rural and sparsely populated areas. Not until the 1950's, more than half of the Swedish population lived in cities. Still around 1900, about $80 \%$ lived in the rural areas. ${ }^{15}$ It is to notice that Swedish public health care policy was motivated out from the idea of the alarming health situation in the cities, in a time when this alarming health situation was a problem to only a minority of the Swedish people. Research on Swedish public health care reforms has to some extent investigated the performance of state policies in local communities, but in cities, and has confirmed them, in the late $19^{\text {th }}$ century, as indeed unhealthy places. ${ }^{16} \mathrm{~A}$ shift in ideas has been made a point of: in

12 Sundin 2005, p. 385-386.

13 See for example, Eklöf 2000, Ling 2004.

14 An interesting question, not to be answered in this context, is if the experiences of the local medical agents may have had impact on the framework and possibilities to change it.

15 Sköld 1996, p. 94-95, Ivarsson 1988, p. 4.

16 Sundin 2005, Sköld 1996, Edvinsson 1992, Nilsson 1994, Edvinsson \& Rogers 2001. 
turn-of-the-century Sweden, the city was seen as an unhealthy place, while the countryside was idealized as natural and healthy, ${ }^{17}$ but in the 1930 's, the countryside was revealed as underdeveloped and unhygienic in the shadow of the welfare state's advance in the cities. ${ }^{18}$ This is interesting. Did the Swedish welfare system never really reach the Swedish countryside and, hence, the majority of the Swedish citizens? Was public health reforms maybe never designed to fit the rural Sweden? The question to what extent - and when, and how - public health care reforms were realized in the Swedish countryside, here stands out as a relevant one.

\section{Questions, material and disposition}

This study aims to say something about conditions and prerequisites for the impact of public health reforms in the Swedish countryside, in a period of time when the first steps were taken to create the Swedish welfare state. Now, the public health care system expanded - with national ambitions, but motivated by urban problems. The question to be answered in this essay is: what was the provincial doctors' own view of their possibilities, as the state's medical experts, to promote public health care in the district?

The main materials used for this study are the provincial doctors' yearly reports to the National Medical Board in Stockholm. The reports have been used in several contexts, principally in "traditional" medical history studies or local history studies. The reports' value as empirical sources has been confirmed, according to their possibilities to give information not only on specific places and individual physicians, but also on public health conditions and the province doctor as a profession. ${ }^{19}$ From a choice of reports from the $19^{\text {th }}$ century, Swedish historian Ylva Sjöstrand points out some interesting aspects on the provincial doctors' view of the modern and the traditional. A common feature of the reports studied is the physicians' generalized descriptions of the locals from a "from above" perspective. According to Sjöstrand, the physicians did share some common, but contradictional, ideas of the locals. The provincial doctors seem to have had an ambivalent attitude to the locals

17 The idealization of the countryside in turn-of-the-century Sweden has been discussed and analyzed by for example Martin Stolare and Nils Edling, Stolare 2003, Edling 1996.

18 Edvinsson \& Rogers 2001, p. 562, Edvinsson 1992, p. 10. The uncovering of the Swedish countryside as underdeveloped and filthy was manifested in a series of reports in Swedish national public radio in 1938, titled Lort-Sverige (Dirty Sweden), documenting the very poor standards of housing and living in the Swedish countryside. The report series was produced by journalist and writer Lubbe Nordström, who also wrote a book with the same title.

19 Swedish historian Karin Johannisson has distinguished three types of history of medicine: traditional, social and critical. Traditional history of medicine is, Johannisson says, written from the perspective of physicians and medical science, often anachronistic, and takes the objectiveness and "truth" of medical knowledge for granted, Johannisson 1990, pp. 13-20. 
citizens in the rural districts. While the physicians sometimes picture themselves as the modern society's represents and the advocates of sense, rationality and science, in other contexts, aspects of the same modernity is described as something bad in contrast to the idealized traditionalism represented by the "good farmer". ${ }^{20}$ This ambivalence can maybe be explained out from the provincial doctors' double roles and loyalties as at the same time the state's represents and the local society's.

The reports were based upon standardized forms. The physician should describe the incidence of different diseases and complaints and the number of children born, but also the "common health condition" in the district on the basis of different factors as, for example, housing conditions and fresh water supply, the local authorities actions in health issues, the number of medical agents practising, ceremonies as forensic medicine autopsies and scientific observations. The yearly reports, then, provide broad information about a region and its population, and not only on health matters.

The reports as a source of primary information do of course have its limitations as well. The information given is always a selection, made by the individual physician. The content of the reports is then not only a matter of what the National Medical Board wished to know, but a matter of what the doctor found worthwhile to tell. The individual character of the reports also results in differences in quantity. Of the 40 reports used for this study, the majority are very detailed, but there are also more moderate writers among the physicians. A lack is that the reports tell very little about the people in need of medical health care. The patients, or presumptive patients, do only occur as numbers in statistic information on diagnoses.

After a brief overview over the provincial doctors' Swedish history and earlier studies of it, the medical district of Sveg 1881-1920 is presented. The study then focuses the prerequisites for public health advances in the district, called attention to and discussed by the provincial doctors' themselves in their reports.

\section{The provincial doctors - earlier studies and background}

Swedish historical research has described the medical profession as one of the most successful ones of the 19th century. The physician's status grew and the physicians increased their influence over the developments of modern society. The physician had the role of medical expert, impartial represent of science and truth teller. ${ }^{21}$

Swedish historical research on occupations in the care section has mainly focused women dominated occupations, and the physician, from a gender perspective, have

20 Sjöstrand 2003, pp. 139-161.

21 This view is common in many studies, as for example Palmblad 1998, pp. 35-37, Johannisson 1991, pp. 150, 155, 170, Björkman 2001, pp. 90-95, Ling 2004, pp. 33-34, Arvidsson 2002, pp. 75-77 and Edvinsson \& Rogers 2001, pp. 548, 562. 
been seen as a masculine profession with supervision over midwives and nurses. Mostly, studies in medical history points out physicians as a male collective with power over women, both other professional groups and patients. ${ }^{22}$

Physicians, then, have been pictured as a homogeneous group, whose power and independency increased rapidly from the end of the $19^{\text {th }}$ century. Beside this picture, anyway, is another, contradictive one. Studies show that physicians did not have that significant power, in society or even over their own professional conditions. The differentiation between the physicians contradicts the image of physicians as a homogeneous collective. No one can question the fact that the profession for a very long time was an exclusively male one - but there are gender history studies that give a balanced picture of the expected patterns of subordination and superiority. For example, female professions as the district nurse often had an independent and important position in relation to the local physician. ${ }^{23}$

When it comes to the provincial doctors, studies are predominantly biographical or local. The harsh working conditions of the provincial doctors are often called attention to, and the province doctor is described as a hero, observing and supervising the local society from a professional, "outsiders" view. The physician here is the represent of progress and development. Interestingly enough, many studies show how the state employed physician competed with other medical agents, and how the physician's personality and social interaction were more important factors in the competition than professional and official authority. ${ }^{24}$

In the 18th century, the Swedish state took the first steps towards a system of state employed physicians. Sweden was divided into medical districts, and a physician was stationed in each of them, a "province doctor". 25 "Province" here refers both to the fact that the system built upon marked off areas, districts or provinces and to the important notion of that this was something that indeed included the rural and sparsely populated areas of Sweden, the provincial Sweden. Or, at least, was meant to.

The motive behind the system was not only that the state should better provide for the citizens' health, but also that the physicians should report back to the state authority, the National Medical Board, about all conditions that concerned the citizens' state of health. ${ }^{26}$ From the very beginning, then, the provincial doctors were

22 Öberg 1996, pp. 90-91, 95, 304, Andersson 2002 pp. 168-172. See also Milton 2001, Nilsson 2003.

23 Arvidsson 2002, pp. 57-58, 66-67, Qvarsell in Sjöstrand (ed.) 2003, p. 16, Emanuelsson \& Wendt, pp. 10-12, 14-15, 18, 85, 186.

24 Abukhanfusa 1994, pp. 34-40, Abukhanfusa in Källor till den svenska historien (Årsbok för Riksarkivet och landsarkiven), 1993, pp. 132-142, Nilsson 2002, pp. 121-127, Appelqvist \& Nilsson 2005, pp. 95-113, Sjöstrand 2003, Järnankar 1997, pp. 33-43.

25 Bergstrand in Kock (ed.) 1963, pp. 120-124.

26 Ibid. 
double agents. As medical experts, they were supposed to supply the local society with public health care and supply the state with information and knowledge of local conditions.

The provincial doctors' working conditions were regulated in a specific instruction. The first instruction was appointed in 1744, but the most important one was that from 1822, which outlined the provincial doctors' conditions until the 1960's. According to the instruction, the physician not only should give medical care and advice to all members of the district, but among other tasks work for preventative medical care, fight epidemics and sexual transmitted diseases, instruct and supervise vaccinators and vaccination against small pox, supervise the district's midwives and dispensers and perform forensic examinations and autopsies. In short, the province doctor should act in every local medical and health issue possible. ${ }^{27}$ The instruction was renewed several times during the $18^{\text {th }}, 19^{\text {th }}$ and $20^{\text {th }}$ centuries, but the main themes remained the same.

The province doctor had a yearly salary combined with a rate system for medical services. A problem was that physicians stationed in very sparsely populated areas naturally earned less than their colleges in more urban districts. This was regulated in 1890 through a so called service benefit, intending to guarantee a certain income for the physician. The medical district of Sveg was one of the districts where the physician was guaranteed such a benefit. ${ }^{28}$

In 1880, the provincial doctors organized themselves in Swedish Provincial doctors' Association (Svenska provinsialläkarföreningen). A change in the instructions in 1890 gave the provincial doctors extended social and political influence as they now became obligatory in the newly established Community Boards of Health, municipal authorities with the task of supervising certain health issues in the local societies. From the end of the $19^{\text {th }}$ century, then, the provincial doctors' possibilities of local influence increased. ${ }^{29}$ But times were to change. During the $20^{\text {th }}$ century, the system of provincial doctors lost importance in relation to the expanding system of public hospitals and the increasing number of hospital physicians. When physicians became more specialised, the province doctor profession, bound to local practice, lost status. ${ }^{30}$

27 Ibid.

28 Svensk Författningssamling 1890:59, Taxa för arfvode àt visse i civil tjenst anstälde läkare för enskild sjukvård och för intyg, meddelade på enskild begäran, äfvensom för tjensförrättningar, verkstälda enligt gällande instruktion eller myndighets uppdrag.

29 Kock 1962, p. 125.

30 Kock 1962, p. 157. 


\section{The Medical District of Sveg: Population, Industries, Communications}

The medical district of Sveg 1880-1920 was part of the Härjedalen province in Jämtland County. The district consisted until 1898 of six smaller municipalities, and after that of five. ${ }^{31}$

Even if the population of this part of Sweden was very small, it increased, especially in the 1880 s and the 1910 s. $^{32}$ In the Härjedalen province, the population growth was especially remarkable after 1900 , in particular in the village of Sveg. ${ }^{33}$ In the district as a whole, the population grew from about 6000 inhabitants in 1881 to more than 9000 in $1920 .{ }^{34}$ Health matters were an issue for the Municipal Boards of the district until 1909, when Sveg had become a society big enough to have a Community Board of Health of its own. ${ }^{35}$

1880-1920, agriculture and animal husbandry was the dominating industry in the county. At the beginning of the 1880 's, almost $90 \%$ of the population were peasants, the majority self depending farmers and crofters. At the end of the $19^{\text {th }}$ century, a new working class emerged, farmhands of both sexes and forestry workers. Until the turn of the century, farming in the district was limited to self support and for a long time unmodern. ${ }^{36}$ An important additional source of income was forestry. The forestry had an impact on the social structure and the population of the district as hundreds of workers came to stay during logging and rafting seasons. This social group of outsiders, young, single men with no families and a non-resident lifestyle, can be expected to have had an impact on the district's health conditions: the workers as carriers of diseases into the district, them passing on venereal diseases, or the forest workers' communities as breeding grounds for epidemics. But surprisingly enough, this is only mentioned once in the provincial doctors' reports, when the doctor claims that the forestry workers' drinking habits has a bad impact on the locals' ditto. ${ }^{37}$

The fact that almost all of the local men also worked in the forestry industry and stayed away from home for long periods is never mentioned in the reports, and neither is the fact that the women too lived away from home during summer, living with the cattle in the pasture lands. This special social structure, where either the man or the woman in the family staying away from home most part of the year, is

31 Provinsialläkarrapport Svegs distrikt 1908 (Provincial Doctor's Report Sveg District: from now on is referred to PDR ) Based upon archive studies of all PDR 1880-1920.

32 Rolén (ed.) 1990, pp. 22-23.

33 Bromée 1974, pp. 122-123.

34 PDR 1903.

35 PDR 1908.

36 Rolén (ed.) 1990, pp. 22-29.

37 PDR 1882. 
mentioned by the priest as having an impact on morality, family bonds and parents' control over their children, but never by the province doctor. ${ }^{38}$

In the district, there were no cities - only small villages, some of them only with a couple of small farms, spread with miles of forests between them. To communicate with and travel to other places was time demanding. In 1889, the district got a telegraph station. The province doctor in charge at the time called this epochmaking, as the district eventually was connected to the "civilized Sweden". ${ }^{39}$ The following year telephone connection was the happening of the year. Telephone, the doctor said, was "invaluable" to health care work. ${ }^{40}$ In the beginning of the $20^{\text {th }}$ century, the district got railway connections to other places in Sweden. The railway improved the communications of the district, but also the food prices and the population's social structure as a new category, the navvies, became part of it during the period of railway building, 1901-1924. ${ }^{41}$ In the reports, the navvies, as well as the forestry workers, are seen as a group separated from the locals, with their own health problems connected to their bad housing and nourishing conditions, but not as having any impact on the district as a whole.

\section{Prerequisites for Public Health}

\section{The State's Experts}

During the period 1880-1920, nine provincial doctors worked after each other in the district. The physicians were all between 30 and 40 years old when they took up their duty. None of them was born or raised in the area, but came as strangers from other parts of the country. It is hard to decide if, and if so, to what extent the province doctor ever became part of the local society. Apparently, some of them did, as L. O. Svenonius (1853-1926), who married a local girl and stayed in Sveg until he died, while others never may have been more than "constant visitors", as the doctor who had his family in the south of Sweden during his eight years of service. $^{42}$

The doctors' own view of themselves as the State's represents is obvious in their yearly reports. This is also a finding of an earlier study, who says that the provincial doctors seem to have applied a from-above-perspective on the locals. In agreement

38 Prestjan 2009.

39 PDR 1889.

40 PDR 1890.

41 Rolén (ed.) 1990, p. 122-125, 149-152, Bromée 1974, p. 123, PDR 1902, 1904, 1908.

42 All information on the provincial doctors are collected from extensive archive studies:

PDR 1880-1920 and Chrush records, Sveg parish. 
with this, the yearly reports from Sveg are filled with indignant and dejected comments about the locals' housing, eating, drinking and cooking habits, infant care, hygiene, ignorance, superstitiousness and suspicion to all that was modern. ${ }^{43}$ "Cleanliness is something unthinkable", a province doctor claims in $1881 .{ }^{44}$

In the earlier study mentioned is talked about an ambivalent attitude: even if the doctors tended to see the locals as "the others" who had to be educated, informed and supervised, on the other hand, they also had a way of defending the locals' way of living as "natural" and "healthy" in contrast to the unhealthy and deprevated lifestyle in the growing cities. Coming to the provincial doctors of Sveg medical district, anyway, there are few if any comments indicating this kind of ambivalence. The provincial doctors here never have anything good to say about the locals' way of life - which is surprising, according to the contemporary idealizing of the countryside and the farmer's healthy life style.

\section{Needs of public health care?}

Were there specific needs for public health care in the medical district of Sveg, caused by specific health problems? Aside from the very common chronic stomach and rheumatic sufferings, the district was ravaged by diseases and epidemics. Especially serious were the problems caused by diphtheria, tuberculosis and, in 1918-1919, the Spanish Flu.

Diphtheria was a serious and very contagious throat disease, and for long times the cause of a great deal of the district's infant mortality. ${ }^{45}$ Even if diphtheria was a sphere where the province doctor - for once, at last - could prove the superiority of medical science, ${ }^{46}$ the disease wasn't discussed in the yearly reports as causing a special need of medical expertise, apart from one or two comments about how death could have been avoided if the provincial doctor had been summoned, at all or earlier. ${ }^{47}$ The same thing can be said about tuberculosis, a disease prevalent in the district during all of the period, or other infectious diseases. ${ }^{48}$ Another example: severe

43 PDR 1880-1920, ibid.

44 PDR 1881.

45 The reports' records of how many fallen ill from diphteria shows that the disease was occuring almost every year 1880-1920. The period 1908-1915, there were very few cases, if any, every year, but in 1916-1920, the disease was emerging again, even if it never reached the level of the 1880 's and 1890 's. In 1884 , the province doctor reports of 30 percent mortality in diphteria. PDR 1880-1920.

46 In 1901, the province doctor reports of a new "serum treatment" that had been found to considerably decrease the mortality from diphteria, PDR 1901. In 1904-1905, the province doctor writes that since the locals have learnt to seek treatment in time, the state of illnesses have been mild, PDR 1904, 1905.

47 PDR 1894, 1898.

48 S. f. e. PDR 1883, 1891, 1897, 1901, 1905, 1908. 
flu epidemics ravaged the district, as the rest of Sweden, in two periods, the "Russian" about 1890 and the Spanish Flu in 1918-1919. In 1890, at least 65 percent of the district's inhabitants fell ill, ${ }^{49}$ and in 1918-1919, the numbers of persons taken ill and died were even higher. ${ }^{50}$ Even if the Spanish Flu was the direct cause of an exploding public health intervention in the district as well as the in county (see later on), ${ }^{51}$ the provincial doctors never discussed the epidemics as giving rise to higher needs for medical expertise.

The occurrence of diseases and epidemics may be expected to have caused the provincial doctors to point out the need of public health efforts and medical expertise in their reports - but this argument wasn't used to advocate their own importance. Instead, it was the locals' traditional way of life that was identified and underlined as the most remarkable threat to state of health that caused the real need of the province doctor's expert knowledge. The provincial doctors' opinions of the locals' way of life was critical. The locals led an unhygienic life, and it was especially their habits of housing and eating that concerned the physicians. Almost every year, the reports mention the local eating habits. The food supplies were sufficient, but according to the provincial doctors the local women had no knowledge, nor interest, of cooking, and because of this, the locals never ate something that wasn't rotten, rancid, sour, dried or salted. ${ }^{52}$ Even if the homes in general were spacious, the whole household crowded in one room, and it wasn't until the 1910's that the locals abandoned the tradition to live under the same roof as their cattle. ${ }^{53}$ The provincial doctors' view of the local traditions of infant care is somewhat contradictional - the mothers are said to breastfeed their children far too long, but at the same time they are accused of giving the babies potatoes, herring and porridge far too early. ${ }^{54}$ And so on. The locals, the provincial doctors declared in 1882, ate

sour, disgusting, half-year-old milk and dried half rotten meat, sour fish, raw pork, coffee with snaps in unreasonable quantities. That this diet eventually will destroy even a harsh farmer's stomach is obvious. ${ }^{55}$

On top of everything, the local women were too lazy to cook:

Attempts to introduce peas, beans and grains in this diet will not succeed, as no local

49 Åman 1988, pp. 74-86, PDR 1890.

50 PDR 1918-1919.

51 Åman 1988.

52 PDR 1880-1920, the cooking and eating habits are mentioned in almost every one of the reports.

53 PDR ex. 1884, 1886, 1889, 1892, 1897, 1904, 1916.

54 PDR ex. 1885, 1893, 1907, 1913.

55 PDR 1882. 
woman is willing to subject herself to the one hour's effort of preparing these foodstuffs....

The locals' particular partial to coffee, or the "coffee abuse", was another concern of the province doctor during the whole period. The amount of coffee consumer by the locals surprised and shocked the doctors. According to the doctors the inability and lack of interest in cooking and the opposition of using new methods of storing food resulted in chronic stomach complaints. ${ }^{57}$

The housing habits of the locals were another thing described as a serious threat to health. In the district, the dwelling houses were spacious timber buildings, heated with a fire place in one of the rooms. The critical points were two. First, all the members of the household usually crowded in one room, where they ate, slept, cooked and worked, regardless the many rooms of the buildings. This was both a practical solution to keep the warmth in a harsh climate and a traditional way of living. Second, it was very common that part of the household, as the old people, the maids or the farmhands, had their lodging in the barn. Even if the provincial doctors through the years agree on the barns as more clean, tidy and healthy as lodging than the dwelling houses, this was found as unhygienic as the crowding problem. The problems with these traditional ways of lodging, according to the doctors, were not only the infectious risk and the problems with isolating and disinfection in cases of illness, but also that the dwelling houses were considered draughty and cold, which caused rheumatic diseases. ${ }^{58}$ The habits of lodging existed to the end of the period, but became, to the province doctor's relief, unmodern and thereby more uncommon from the first years of the $20^{\text {th }}$ century. ${ }^{59}$

It was, then, the locals' traditional way of life that, due to the provincial doctors, made the medical experts' knowledge and advice a necessity in the medical district of Sveg - not the existence of diseases and epidemics. This was of course subjective judgements and besides that, as we have seen, possibly part of a tradition where provincial doctors used a condescending jargon to express their understanding of the locals and their way of life as conservative.

56 PDR 1891.

57 S. f. e. PDR 1881, 1885, 1887, 1891, 1901, 1915, 1916, 1919, 1920. Even if 17 (!) cups of coffee a day certainly can be seen as over-consumption, one should keep in mind that the frequently debated Swedish "coffee abuse problem" of the late 1800's and early 1900's also should be seen in the light of a tendency to, from a moral point of view hidden behind health arguments, problematize all so called luxury consumtion among the lower classes.

58 PDR ex 1884, 1886, 1889, 1892, 1897, 1904, 1916.

59 S. f. e. PDR 1908, 1912, 1915, 1920. 


\section{The public health force: state authorised medical agents}

In the district, there were of course other medical agents than the province doctor. Some of them can be said to have reinforced public health's position in the district, as members of a public health "force", while others meant competition and challenge. Let's start with the public health force that besides from the province doctor consisted of midwives and nurses. Midwives and nurses were, as the doctor, professionals and authorised by the state, and, even if not state employed, public employed and not private entrepreneurs. An increasing number of midwives and nurses in the district, then, mark the expanding public health care system and the medical experts' grip of the medical marketplace.

In the Sveg district, there were at the beginning of the period 1880-1920 only three midwives. The lack of educated midwives concerned the provincial doctors. Giving birth should be supervised by medicine. But as the cost of a midwife was a municipal responsibility, not all municipals could afford, or prioritized, this service. Information on the numbers of childbirths assisted by a midwife can only be found in reports from the years 1886-1889, and varies between 40 and 50 percent. The low number of midwives in the district, the far distances and the bad communications were not, anyway, the only reasons to the locals to not chose one of state's medical experts when giving birth. According to the province doctor, the locals preferred to engage help women or help men rather than the local midwife, even if the latter lived closer. This is an example of how there was a lack of confidence in the public health care, and a higher confidence in the traditional resources, independent of availability.

Until 1901, the provincial doctor was the only deliverer of public health care in the district, assisted by the midwives and the small pox vaccinators. With the opening of a small cottage hospital in Sveg village - the result of private fund raising and persuasion of the municipalities to make contributions - a professional nurse was engaged by some of the district's municipalities, who eventually had agreed to pay for this service. ${ }^{60}$ The cottage hospital was the very first institutional effort of the district, and it is important to notice its half-public, half-private character. The cottage hospital nurse reinforced public health's force of medical experts, but any remarkable reinforcement didn't take place until the years of 1918-1920, when a fast expansion occurred. This was the result of the meeting of direct needs - the influenza epidemic of 1918-1919 - and of renewed public reactions to an old problem - the tuberculosis.

1918, a municipality nurse was engaged by the Sveg municipality, with economical contributions from the forestry companies. Two years later, three of the district's six municipalities had their own nurse. 1918 was also the year when the

60 PDR 1901-1920. 
influenza epidemic called the Spanish Flu ravaged Sweden. The Sveg district did not escape its advance, and almost a third of the districts' inhabitants fell ill. This year, no less than nine extra nurses and two help nurses did service in different areas of the district, and temporary epidemic hospitals were set up. ${ }^{61}$ The same year a tuberculosis clinic, a so called dispensär, with a tuberculosis nurse, was arranged in Sveg village. In the district, tuberculosis was common from the beginning of the period. ${ }^{62}$ People died from tuberculosis every year - in 1889, 10 percent of all deaths were the result of tuberculosis. ${ }^{63}$ The tuberculosis situation in the district was not especially alarming in 1918 compared to earlier years, and the dispensär reform was rather the result of contemporary medical progress in the field as well as increased social interest for tuberculosis as a problem than of an alarming situation. The aim of the national dispensär activities was mainly preventive measures to prevent spreading of the infection and increase resistance to it, and its activities were mainly based upon philanthropy. The dispensär nurse visited all parishes of the district at some times of the year, to deliver information on the disease and the contagiousness, and assist with care and hygiene in the homes. The system was, though founded in philanthropy, part of an early, public non-institutional care system, where medical professionals practiced in local societies and implemented public health care. ${ }^{64}$

\section{Competition}

The public health reinforcements then reached the medical district of Sveg district late. Until 1918, the province doctor was all alone, besides from the very few midwives and vaccinators. The midwives, anyway, weren't always the doctor's allies, they could also be challengers. In 1897, the province doctor for the first time mentions a midwife, who "pretty much is engaged outside her profession" ${ }^{65}$ and a few years later, he is really upset over the enterprising midwives:

...the midwives are engaged to cure all kinds of complaints that do not have anything

61 PDR 1918. Margareta Åman has written about the Spanish Flu in Sweden and Jämtland County. The flu came to Sweden summer 1918. Östersund, the one city in Jämtland County, was one of the most striked Swedish cities with extremely high mortality rates, Aman 1988, pp. 74-86.

62 PDR 1886.

63 PDR 1889. See also PDR 1884-1889, after this year, the tuberculosis patients are reported separately and do not appear in the yearly reports of the provincial doctors.

64 PDR 1918, 1919. See Sundin 2005, pp. 405-406, who points out that the public and the private initiatives often were each others' complement and supplements during the period, and Seip 1984, who defines 1870-1920 as a period of cooperation between public and private and a forerunner to the welfare state thinking of the 1930's and on, when public responsibility increased, Seip 1984, pp. 12-13; Beskow \& Wiman 2006, pp. 1229-1230.

65 PDR 1897. 
to do with their profession... I say, the midwives of Lillherrdal and Ytterhogdal have the functions of ordinary nurses, nota bene: who also prescribe the treatment. But what to do? The public want it that way, as the midwife in their opinion always is a kind of doctor. ${ }^{66}$

Not only factors connected to the presumptive patients' preferences and the suppliers of medical health care are of importance when it comes to what extend public health care can succeed in a local society. Another thing important is the relation between different medical agents. This relation is usually expressed as competition, between qualified and un-qualified healers, ${ }^{67}$ or between different professions, ${ }^{68}$ but can also be about cooperation, dependence or complement - something that has been established by for example Swedish historians Agneta Emanuelsson and Rigmor Wendt concerning the relation between provincial doctors and district nurses. ${ }^{69}$ As we have seen, there are possibilities to inquire into the provincial doctors' relations to, for example, the midwives, who apparently could be both allied, supervised subjects and competitors. In this study, though, the relation focused is the competition between the province doctor and the quack.

The disobedient midwives were not a major problem to the provincial doctors in Sveg district. They had more serious competitors in the local quacks, or, rather, The Local Quack. In the district, one man, mill owner Anders Wallström, practiced medicine during the whole period 1880-1920. The history of this business is enough for a book of its own, and much has been written about Wallström and his feats. He is still today kind of a local historical hero, and the province doctor are in these stories the narrow-minded, ridiculous man who tries to charge Wallström, but always get cheated. There are several stories of how the public confidence in the medical expert was low, compared to the unlimited faith in Wallström's capacities and methods. ${ }^{70}$

The provincial doctors' reports give a similar picture of the situation. Wallström is mentioned every single year. There were other medical swindlers as well, as masseurs, hypnotizers and homeopaths, ${ }^{71}$ but even if they too indeed were seen as competitors by the provincial doctors, they were nothing compared to the miller.

In some cases, the province doctor admitted the value of the unauthorized healers. The acceptance of quacks was of course also due to the doctor's attitudes. Some of the quacks so were judged reliable and useful, and even a valuable resource, as they limited their practice to their own village and cooperated with the

66 PDR 1900.

67 See for example Eklöf 2001, Ling 2004.

68 See reference 25.

69 Emanuelsson \& Wendt 1994, t. ex. s. 10-12, 14-15, 18, 85, 186. Se också Jenner \& Wallis 2007, s. 14.

70 S. f. e. Wahlquist 2003.

71 S. f. e. PDR 1889, 1900, 1909, 1910, 1917, 1920 
physician. ${ }^{72}$ Axel Möller (1853-1924), province doctor of the district 1884-1892, wrote:

I personally consider humans masters of their own bodies, and that they have the right to ask anyone they wish for advice when these bodies let them down or cause them pain. I therefore do not attach any importance at all to Wallström's appearance as a doctor. ${ }^{73}$

The district was large, the communications few and so the public health resources, he wrote:

Here, where the doctor is far off, [the quacks] are necessary and often even useful, especially as they do request alarming cases to the physician. ${ }^{74}$

For the most part, though, the provincial doctors, and even Möller, agreed upon Wallström as a greedy, overestimated, self-righteous and dangerous charlatan. Wallström did not limit his practice; on the contrary he extended it and treated patients even in other districts. ${ }^{75}$ His practice included writing of prescriptions (accepted at the district pharmacy), production and selling of his own patent medicine, purchasing medicaments directly from his own illegal storage and all kinds of treatments, from internal to chirurgic. ${ }^{76}$

The provincial doctors' discontent with Wallström rose from two contexts: the quack's trespassing into the areas of the authorized medical experts, and the public's unlimited confidence in and support of the quack. The trespassing could be met with legal measures, as there were laws against illegal trade with pharmaceutics and unauthorized medical practice. ${ }^{77}$ Wallström was reported and put on trial, and even judged a few times, but his outstanding reputation was always an obstacle to his accusers. Wallström extended his practice. In 1889, Wallström was engaged as "district medical officer" in one of the district's parishes. The municipality payed Wallström to hold regular receptions in the parish four times a year. According to the province doctor, people flocked in large numbers, sick or healthy, to see Wallström. The business was a very profitable one: each patient payed a fee, divided between the quack and the municipality. ${ }^{78}$ Wallström's receptions went on until at least 1920, and through the years, he extended his business to other parishes inside the district. ${ }^{79}$

72 PDR 1885, 1890.

73 PDR 1886.

74 PDR 1885.

75 PDR 1885.

76 PDR 1881-1920.

77 Ling 2004, passim.

78 PDR 1895.

79 PDR 1903, 1915, 1920. 
This was, of course, a defeat to the province doctor of the district. In the 1890's, the province doctor's possibilities to outreach work and extended public health services improved. If a parish wished regular, local receptions of the province doctor, the municipality had to pay for wood, make premises available and pay a reasonable compensation to the doctor for travel expenses. The fact that a municipal committee rather payed for the services of a quack than for the authorized physician's, and even payed the quack more, was unconventional and of course a struck to the doctor's professional pride. ${ }^{80}$

In 1892, anyhow, one of the district's municipalities made an economical agreement with the state, and the province doctor from this year on held regular receptions there. ${ }^{81}$ In 1898 , the province doctor made efforts to hold receptions in "Wallström parish". The province doctor found these receptions very important, as the locals of this parish were "more than usual prejudiced and ignorant in health matters". By then, the communications were improved as a new main country road was prepared. ${ }^{82}$ The province doctor established that his receptions not at all had had any effect on the quack's popularity, but that the public health's efforts were necessary as a counterbalance. ${ }^{83}$ In 1909 , the province doctor could extend his activities with regular receptions to two more parishes of the district. But by this time, Wallström the quack had had his receptions in these places for several years. ${ }^{84}$

According to the provincial doctors, the Wallström problem had three explanations: the insufficient legal means, ${ }^{85}$ the disregard of the local authorities, ${ }^{86}$ and the locals' ignorance and stupidity. ${ }^{87}$ It was very easy, was a province doctor indignant statement, to accuse and convict a legitimized physician, but very hard to achieve any legal consequences when it came to the quack and his activities. ${ }^{88}$ And when Wallström eventually was fined, the public raised funds to pay his penalties. ${ }^{89}$ The confidence in the quack seems to have been astonishing - even if there were several cases where Wallström's mistakes led to complications, invalidity and even death, the locals kept their confidence, probably maintained by the man's almost mythological status. ${ }^{90}$ During the whole period the locals' ignorance is a recurring theme in the provincial doctors' reports. The locals are called naïve, foolish, superstitious

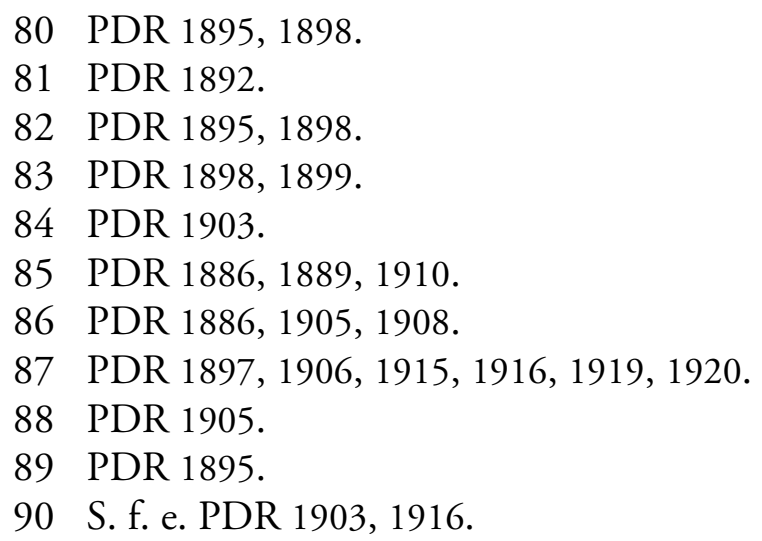


and stupid, something that appears to be the most important reason to Wallström's success. ${ }^{91}$

\section{Public Health in the District of Sveg 1880-1920: Summary, Conclusions and Discussion}

Even if public health care in Sweden expanded fast in the period of 1880-1920, in Sveg medical district, there was no noticeable development of public health until the very end of the period. The district went through several changes: the population increased, the communications improved and the railway and forestry industries grew more important. But it was not until the last years of the period that any remarkable increase in the reach of public health took place. This sudden expansion was then the answer to one new and one old problem: the Spanish flu epidemic and the renewed interest for the tuberculosis problem.

The provincial doctors, anyway, from the beginning of the period saw considerable needs of medical expertise in the local society. Those needs were not, as may be expected, related to the geographical place's specific demographic and social structures, or to the occurring of serious diseases and epidemics. Instead, the provincial doctors justified their presence as medical experts and public health agents referring to the locals' way of living and their ignorance of scientific principles for hygiene and medicine. The most common complaints of the district, stomach problems and rheumatism, were directly connected to the locals' lifestyle. The provincial doctors' role in local society in reality, then, seems to have been wider than experts in strict medical matters - they seem to have taken the responsibility of teaching the locals a modern way of living. Almost everything in the locals' way of life had, according to the provincial doctors, effects on their state of health. This is something that stands in accordance with the contemporary way of translating all social matters into science, preferably medical science. The definition of "medical matters" then was widened.

According to the provincial doctors' yearly reports, there were several thinkable obstacles to public health's and the medical expert's problems with getting a grip of the medical district. The army of medical expertise was small, the communications of the district was bad and people were poor. But it seems as if lack of confidence in authorized medicine and its represents was the most important explanation to public health's deficient successes. The consumers' demand for medical services is depending on need, purchasing power and confidence. ${ }^{92}$ Confidence is something

91 PDR 1897, 1906, 1915, 1916, 1919, 1920.

92 S. f. e. Kearns, Lee, \& Rogers in Clark Nelson \& Rogers (eds.) 1989, pp. 9-81, Eklöf 2001, pp. 36-45. 
that is created between the medical agents and the consumers of their services, and is by Swedish historian Motzi Eklöf called "a decisive prerequisite" for a physician's success in a local society in competition with other physicians and practicians. ${ }^{93}$ The question of confidence is connected to the constant presence of a mighty competitor: the local quack. Even if the medical district of Sveg was gifted - or cursed with a quack of mythological status even in his own time, the continuing presence of other unauthorized healers stood out as a general problem to the provincial doctors. The locals' confidence in the quacks corresponded to their lack of confidence in the province doctor. Poor access to public health - bad communications and few medical experts - might be an explanation. This is contradicted, though, by the fact that an un-authorized healer often was engaged even if there was an authorized one at hand.

Why, then, this lack of confidence in the state's medical expert? The consumers' confidence in a medical agent can be based upon the agent's medical knowledge, professionalism and successful treatment results. Eklöf, however, emphasizes personal qualities and reputation as very important to confidence, ${ }^{94}$ and British historians Mark Jenner and Patrick Wallis in the same way point out the importance of the medical agents' integration in local social networks. ${ }^{95}$ As we have seen, the provincial doctors in Sveg district don't seem to have looked upon themselves as part of the local society, but rather as more or less temporary visitors, and ambassadors of modern and civilised Sweden. The yearly reports picture the doctors as persons in authority, with a distinct from-above-view of the locals. In this way, the province doctor cultivated his own role as medical expert and state represent, and created a distance between him and the inhabitants of the district.

Finally: how important was the province doctor as the state medical expert to local implementation of public health? The material used for this study can only give a notion of how the provincial doctors themselves felt in this matter. The provincial doctors 1890-1920 seem to have shared the understanding of themselves as representatives of medical science and the Swedish state. The provincial doctors' real influence and power to carry out public health reforms and special public health efforts, is harder to analyse. The provincial doctors seem to have agreed upon their important assignment, and upon their importance in modernizing the Swedish countryside, but there is also an agreement upon the limited possibilities of implementation.

The question of the medical experts' significance in the development of public health at the Swedish countryside remains here unanswered, then, until new source materials can shed light over the issue. Here, materials as for example the Local Health Board's records, local press and the provincial doctors' own periodical Eira,

93 Eklöf 2001, p. 36.

94 Eklöf 2000, p. 37.

95 Jenner \& Wallis 2007, passim. 
certainly will consitute a base for a following study. So far, one can establish that yes, there were competitors to the state's medical expert in the medical district of Sveg, confidence stands out as the most important factor in public health strivings to dominate the district's health care and no, in 1880-1920, the implementation of public health in the district did not follow the district's societal development.

Anna Prestjan is PhD in history, since 2009 associated to Centre for Feminist Social tudies, Örebro university. 


\section{References}

\section{Literature}

Abukhanfusa, Kerstin, "En svala i historiens stora liggare", Källor till den svenska historien (Årsbok för Riksarkivet och landsarkiven), 1993, p. 132-142.

Abukhanfusa, Kerstin (1994), "Rapporter från rikets provinser", Populär historia 1994, nr 6, p. 34-40.

Andersson, Åsa. (2002) Ett högt och ädelt kall: kalltankens betydelse för sjuksköterskeyrkets formering 1850-1933. (Diss.) Umeå universitet.

Appelqvist, Malin \& Nilsson, Peter, "Folkhälsan i östra Skåne 1860-1899 - en studie utifrån provinsialläkarrapporter", Svensk Medicinhistorisk Tidskrift 2005:9:1, p. 95-113.

Arvidsson, Maria. (2002) När arbetet blev farligt. Arbetarskyddet och det medicinska tänkandet 1884-1919. (Diss.) Linköping studies in arts and science 254, Linköpings universitet.

Berge, Anders, Sjukvårdens underklass. Sjukvården i den kommunala fattigvården 1900-1950 (Umeå: Borea 2007).

Bergstrand, Hilding (1963), "Läkarekåren och provinsialläkareväsendet", Kock, Wolfram (ed.), Medicinalväsendet i Sverige 1813-1962, p. 107-156.

Bernsen, Martin (1993), "Sosialpolitikk og risikoforvaltning: Om forutsetninger for institusjonalisering av arbeidervern og sosialforsikring i Norge og Sverige 1880-1920”, Ervik, Rune \& Kuhnle, Stein (eds.) 1993, Kunnskap, Risiko og Sosialpolitikk: Institusjonelle perspektiver på skandinavisk utvikling.

Beskow, Rigmor \& Wiman, Lars-Gösta (2006), ”Understödsbyrån för tuberkulösa i Uppsala - ett 100-årsminne", Läkartidningen 2006-04-11.

Björkman, Jenny, Vård för samhällets bästa. Debatten om tvångsvård i svensk lagstiftning 1850-1970. (Diss.) (Uppsala universitet. Stockholm: Carlsson 2001)

Bromée, Nils, En bok om Sveg och Härjedalen. (Östersund: Wisénska bokhandeln 1974).

Clark Nelson, Marie, "Frågor kring pest och kolera: Sverige, Europa och den svenska hälsopolitikens utveckling vid 1900-talets början", Att se det osedda: vänbok till Ann-Sofie Oblander, (Stockholm: Hjalmarson \& Högberg, 2006), p. $98-113$.

Edling, Nils, Det fosterländska hemmet. Egnahemspolitik, småbruk och hemideologi kring sekelskiftet 1900. Diss. Stockholms universitet (Stockholm: Carlsson 1996).

Edvinsson, Sören \& Rogers, John 2001, "Hälsa och hälsoreformer i svenska städer kring sekelskiftet 1900", Historisk Tidskrift 2001:4, p. 541-564. 
Edvinsson, Sören, Den osunda staden. Sociala skillnader i dödlighet i 1800-talets Sundsvall (Diss. Umeå universitet 1992).

Eklöf, Motzi 2001, "Förtroendets kapital. Om läkekonstens förutsättningar på den medicinska marknaden", Kulturella perspektiv: svensk etnologisk tidskrift 4, s. 36-45.

Eklöf, Motzi, Läkarens ethos. Studier i den svenska läkarkårens identiteter, intressen och ideal 1890-1960. (Diss.) Linköping studies in arts and science 216 (Linköpings universitet 2000).

Emanuelsson, Agneta \& Wendt, Rigmor, I folkhälsans tjänst. Sju decennier med dens svenska distriktssjuksköterskan (FoU.rapport 43).

Erikson, Robert, "Svensk välfärdsforskning", Socialvetenskaplig tidskrift 2003:2-3, p. 214-137.

Esping-Andersen, Gösta, "Jämlikhet, effektivitet och makt", Thullberg, Per \& Östberg, Kjell (eds.) 1994, Den svenska modellen, s. 75-106.

Ivarsson, Tore, Från fattigvård till välfärd (Stockholm: Svenska kommunförbundet 1988).

Jenner, Mark \& Wallis, Patrick 2007 (eds.), Medicine and the Market in England and its Colonies, c. 1450-c. 1850.

Johannisson, Karin, "Folkhälsa: det svenska projektet från 1900 till 2:a världskriget”, Lychnos 1991, s. 139-195.

Johannisson, Karin, Medicinens öga. Sjukdom, medicin och samhälle - medicinska erfarenheter (Stockholm: Norstedt 1990).

Järnankar, Frans, "'Ett ohyfsat men fromsint folk'. Härjedalen på Johan Ellmins tid", Jämten 1997, vol. 90, p. 33-43.

Kearns, Gerard, "Introduction: Urbanisation and the Epidemiologic Transition", Nelson, Marie C. \& Rogers, John (eds.) 1989, Urbanisation and the Epidemiologic Transistion, p. 7-81.

Kearns, Gerard, Lee, Robert W. \& Rogers, John, "The interaction of political and economic factors in the management of urban public health", Clark Nelson, Marie \& Rogers, John (eds.), Urbanisation and the epidemiologic transition, Uppsala: Uppsala universitet 1989, p. 9-81.

Kock, Wolfram (ed.), Medicinalväsendet i Sverige 1813-1962 : utgiven med anledning av Kungl. Medicinalstyrelsens 300-årsjubileum (Stockholm : Nordiska bokh. 1963).

Larsson, Katarina, Andrahandskontrakt i folkhemmet. Närmiljö och kvinnors förändringsstrategier. (Diss.) Örebro studies in history 4 (Örebro universitet 2004).

Ling, Sofia 2004, Kärringmedicin och vetenskap. Läkare och kvacksalverianklagade $i$ Sverige omkring 1770-1870. (Diss.) Studia historica Upsaliensia 212, Uppsala universitet (Stockholm: Elander Gotab 2004).

Lundqvist, Torbjörn, "Den nya folkhälsopolitikens framväxt: styrning från socialt och ekonomiskt perspektiv", Historisk Tidskrift 2001:4, p. 751-766. 
Milton, Lena, Folkhemmets barnmorskor: den svenska barnmorskekårens professionalisering under mellan- och efterkrigstid. (Diss.) Studia historica Upsaliensia 196 (Uppsala universitet 2001)

Nilsson, Hans, Mot bättre hälsa. Dödlighet och hälsoarbete i Linköping 1860-1891 (Diss.) Linköping studies in arts and science 105 (Linköpings universitet 1994).

Nilsson, Peter, "Folkhälsan i Östskåne under mitten av 1800-talet speglad via en provinsialläkares arbete", Svensk Medicinhistorisk Tidskrift 2002:6:1, p. 121127.

Nilsson, Ulrika, Kampen om kvinnan: professionalisering och konstruktioner av kön i svensk gynekologi 1860-1925 (Diss.) Skrifter / Institutionen för idé- och lärdomshistoria, Uppsala universitet 31 (Uppsala universitet 2003).

Palmblad, Eva, Medicinen som sambällslära (Diss.) Historia och samhällsvetenskap, Göteborgs universitet (Göteborg:Daidalos, 1990).

Perkin, Harold James, The rise of professional society: England since 1880 (London: Routledge 1989).

Prestjan, Anna, Präst och karl, karl och präst. Kristen manlighet i tidigt 1900-tal, (Lund: Sekel Bokförlag/Isell \& Jinert, 2009/2010).

Qvarsell, Roger \& Torell, Ulrika (eds.), Humanistisk hälsoforskning - en forskningsöversikt, SHS 30 (Linköping: Linköping University 2000).

Qvarsell, Roger 1991, Vårdens idéhistoria.

Qvarsell, Roger 1994, '’Ett sunt folk i ett sunt samhälle', Hälsoupplysning, hälsovård och hälsopolitik i ett idéhistoriskt perspektiv", in Carlsson, Gösta \& Arvidsson, Ola (eds), Kampen för folkhälsan. Prevention i historia och nutid, p. 76-108.

Qvarsell, Roger 2003, "Läkaren mellan vetenskap och samhälle”, Sjöstrand, Nils O. (ed.) 2003, in Ett sekel med läkaren i fokus. Läkarförbundet 1903-2003, p. 151167.

Rolén , Mats, Jämtlands och Härjedalens historia. D. 5, 1880-1980 (Östersund: Jämstlands läns museum 1990).

Seip, Anne-Liese, Sosialhjelpstaten blir til: norsk sosialpolitikk 1740-1920 (Oslo: Gyldendal 1984).

Sjöstrand, Ylva, "Modernitet och traditionalism i svenska provinsialläkarberättelser 1851-1874", Svensk Medicinhistorisk Tidskrift 2003 (7):1, p. 139-161.

Sköld, Peter, "Hälsovårdsforskning i de kommunala arkiven", Arkiv Forskning Kultur 1996, p. 94-115.

Stolare, Martin, Kultur och natur: moderniseringskritiska rörelser i Sverige 19001920 (Diss.) Avhandlingar från Historiska institutionen i Göteborg 34 (Göteborgs universitet 2003).

Sundin, Jan, "Vägen mot ett längre liv" in Carlsson \& Arvidsson (eds.) Kampen för 
folkhälsan, p. 33-75 (Stockholm : Natur och kultur i samarbete med Forskningsrådsnämnden, FRN 1994).

Sundin, Jan, "Folkhälsa och folkhälsopolitik" in Sundin, Jan, Hogstedt, Christer, Lindberg, Jacob \& Moberg, Henrik (eds.) 2005, Svenska folkets hälsa i ett historiskt perspektiv, s. 363-470.

Sundin, Jan, Hogstedt, Christer, Lindberg, Jacob \& Moberg, Henrik, "Inledande kommentarer". In Sundin, Jan, Hogstedt, Christer, Lindberg, Jacob \& Moberg, Henrik eds. 2005, Svenska folkets hälsa i ett historiskt perspektiv (Statens folkhälsoinstitut R 2005:8.

Wahlqvist, Åke 2003, Anders Wallström : Soln-Anders 1841-1921 : naturläkare.

Åman, Margareta, "Spanska sjukan 1918 i internationellt, svenskt och jämtländskt perspektiv", Jämten 1988, p. 74-86.

Åmark, Klas, Hundra år av välfärdspolitik. Välfärdsstatens framväxt i Norge och Sverige (Umeå: Boréa 2005).

Öberg, Lisa, Barnmorskan och läkaren: kompetens och konflikt i svensk förlossningsvård 1870-1920. Diss. Stockholms universitet. (Stockholm: Ordfront 1996).

\section{Archive Sources}

Province Doctor's Reports, Sveg district, (PDR SD) to national Board of Health, $1880-1920$.

Svensk Författningssamling 1890:59.

Church Records, Sveg Parish, 1880-1920. 